\title{
Effects of Salt Concentration and Drying Time on the Quality Characteristics of Pork Jerky during Dehydration
}

\author{
Han-Sul Yang, Sung-Won Kang, Seon-Tea Joo, and Sung-Gil Choi* \\ Division of Applied life Science, Graduate School, Institute of Agriculture \& Life Sciences, \\ Gyeongsang National University, Jinju 660-701, Korea
}

\begin{abstract}
This study was conducted in order to evaluate the effects of brine pre-soaking at different concentrations and drying time on the quality characteristics of pork jerky. The physicochemical properties of pork jerky including final moisture content, water activity $\left(\mathrm{a}_{\mathrm{w}}\right)$, shear force, microstructure, and thiobarbituric acid reactive substance (TBARS) values were investigated. The sensory attributes of pork jerky were evaluated and used as parameters for determining the optimum drying condition. The sliced pork samples were pre-soaked at salt concentrations ranging from 0 to $10 \%$ for $3 \mathrm{~h}$ and then dried at $70^{\circ} \mathrm{C}$ for up to $10 \mathrm{~h}$. The pre-soaked samples in the salt solution showed higher final moisture content than the control sample after drying for $10 \mathrm{~h}$. The final moisture content of pork jerky increased with increasing salt concentrations. On the other hand, the water activity with regards to the pre-soaked samples in a $10 \%$ salt solution showed the lowest value for up to $8 \mathrm{~h}$ drying. The shear force values of pork jerky decreased with increasing salt concentration while the TBARS values of the samples increased with increasing salt concentrations. Sensory evaluation suggested that the color, flavor, juiciness, and tenderness of the pork jerky samples were improved by pre-soaking in a $2 \%$ salt solution and the highest likeability score of pork jerky among the samples were obtained by pre-soaking in a $2 \%$ salt solution prior to drying.
\end{abstract}

Key words: pork jerky, salt concentration, drying condition, optimization, sensory evaluation

\section{Introduction}

Jerky is a product that is easy to prepare, lightweight, and rich in nutrient content (Harrison et al., 1997). Jerky is also relatively simple to process, has a typical flavor, and needs no refrigeration during commercial distribution due to its low water activity $\left(\mathrm{a}_{\mathrm{w}}\right)$. Numerous recipes for making jerky are available and they are based on using meat from several species, applying different marinate techniques, and varying drying processes. The final product reaches an $\mathrm{a}_{\mathrm{w}}$ of 0.70-0.75 when ready for consumption, and is normally shelf stable for 6 months if left unpacked to inhibit microbial activity (Torres et al., 1994). Hurdles to microbial survival and growth include drying temperature, low $\mathrm{a}_{\mathrm{w}}(<0.85)$, and preservatives such as salt and organic acids depending on the composition of the marinate mixture (Gailani and Fung, 1986; Quinton et al., 1997). It is essential that intermediate moisture (IM)

*Corresponding author: Sung-Gil Choi, Division of Applied Life Science, Gyeongsang University, Jinju 660-701, Korea. Tel: 82-55-772-1906, Fax: 82-55-772-1909, E-mail: sgchoi@ gnu.ac.kr meat products such as jerky should be dried to water activity acceptable for proper shelf-life.

The osmotic dehydration process can be characterized by equilibrium and dynamic periods (Rahman, 1992). In the dynamic period, the mass transfer rates are increased or decreased until equilibrium is reached. The study of the equilibrium state is necessary for the modeling of osmotic process until operation and also important for a good understanding of the mass transfer mechanisms involved in this system (Barat et al., 1998). The distribution coefficient for processed pork jerky is defined as the ratio of the salt concentration in pork muscle and salt at equilibrium in the drying condition. Although a variety of compounds can be used in curing meat, the basic curing ingredients are salt, sugar, and some other sweeteners. The osmotic agents more employed are hypertonic solutions of salt and sugar and also, ternary mixtures with both compound (Chenlo et al., 2006).

The dimensionless parameter that evaluates the water transferred from the sample is denominated as water loss. Salt (sodium chloride), in particular, produces a strong decreased water activity and higher osmotic pressures than the same sugar concentration used (Lazarides et al., 
1995). An acceptable level of salt in hams has been reported to be about 2-3\% (Pearson and Wolzak, 1982). Of course, higher and lower salt levels are common and are a matter of personal preference. Previous published work has demonstrated improved yields, tenderness, and moisture retention (Detienne and Wicker, 1999). However, published studies have not included optimization of marinate technology in pork jerky.

The objective of this study is to investigate the effects of pre-soaking salt concentration and drying time on the physicochemical and sensory properties of pork jerky to manufacture the products according to consumer likeability and shelf-life safety using pork loin muscle.

\section{Materials and Methods}

\section{Preparation of dried pork jerky samples}

The muscle (longissimus dorsi) of fresh pork was purchased from a local processor at $48 \mathrm{~h}$ postmortem. The $\mathrm{pH}$ of the pork loin was 5.54-5.58. All subcutaneous and visible connective tissue were removed from the fresh muscles. After dissection, all muscles were frozen and stored at $-20^{\circ} \mathrm{C}$ until use (within $2 \mathrm{~d}$ ). The frozen pork was thawed at $4^{\circ} \mathrm{C}$ overnight, sliced to $0.5 \mathrm{~cm}$ thickness with a meat slicer (HFS 350G, Hankook Fugee Industries Co. Ltd., Korea), and cut into pieces of $10 \times 4.0 \times 0.5 \mathrm{~cm}^{3}$ size. Sliced pork jerky samples were cut in the same direction as the muscle fibers. Salt was purchased from a local food additives plant. The sliced pork samples were added different salt amounts from 0 to $10 \%$ (based on raw meat weight; $\mathrm{v} / \mathrm{w}$ ) for time ranging 0 to $10 \mathrm{~h}$ at $70^{\circ} \mathrm{C}$ using dryer (DS80-1, Dasol Scientific Co. Ltd., Korea). After drying and cooling at room temperature, samples were measured for moisture content, water activity, shear force, SEM (scanning electron microscope), lipid oxidation (2-thiobarbituric acid reactive substance), and sensory evaluation.

\section{Moisture content and water activity}

Moisture content was determined according to AOAC (2000). The strips were dried in an air oven at $102^{\circ} \mathrm{C}$ for $4 \mathrm{~h}$ and the total moisture content of individual pork strips was determined from their pre-dry and dry weights expressed as the percentage of pre-dry weight and gram water per gram dry weight.

Three pieces of pork jerky samples from each treatment were selected and cut into fine pieces using sharp scissors. The pieces were filled into water activity cups, and their water activity was measured with a water activity meter (AQS-2, Nagy mess system, Germany), calibrated at ambient temperature $20^{\circ} \mathrm{C}$ with distilled water $\left(\mathrm{a}_{\mathrm{w}}=\right.$ $1.000)$ and saturated solutions of $\mathrm{NaCl}\left(\mathrm{a}_{\mathrm{w}}=0.756\right)$ and $\mathrm{KCl}\left(\mathrm{a}_{\mathrm{w}}=0.853\right)$.

The data analysis for the relationship between water activity and moisture content of jerky products at various drying times was performed by the Microsoft Office Excel Program manufactured by Microsoft Corp., Roselle, IL, USA (Yang et al., 2009). The predicted curve was obtained by fitting experimental data to the equations following the exponential curve of different salt concentrations for soaking.

$$
\begin{aligned}
y= & 0.1915 \mathrm{e}^{5.6425 \mathrm{x}}(0 \%), 0.3194 \mathrm{e}^{5.3086 \mathrm{x}}(2 \%), \\
& 0.6636 \mathrm{e}^{3.9337 \mathrm{x}}(5 \%) \text {, and } 1.6426 \mathrm{e}^{4.7359 \mathrm{x}}(10 \%)
\end{aligned}
$$

Where $y$ is the predicted moisture content, $x$ is $\mathrm{a}_{\mathrm{w}}$

\section{Shear force}

Shear force $\left(\mathrm{kg} / \mathrm{cm}^{2}\right)$ was measured using the Instron Universal Testing Machine (Model 3343) with a Vshaped shear blade. From each six samples, as close as practicable to $0.5 \times 4.0 \mathrm{~cm}$ (approximately $2.0 \mathrm{~cm}^{2}$ ) crosssection (across to the fibers) was cut for cutting force measurements. The pork jerky samples were placed at right angles to the blade. The crosshead speed was 100 $\mathrm{mm} / \mathrm{min}$ and the full scale load was $50 \mathrm{~kg}$.

\section{Microstructure}

The microstructure changes in pork jerky was evaluated using a field emission scanning electron microscope (FE SEM; XL30S, Philips, Netherlands) after preparing the samples by a method reported previously (Carroll and Lee, 1981). The specimens (muscle; $3 \times 4 \times 5 \mathrm{~mm}$ ), cut longwise to the muscle fibers, were fixed with $2.5 \%$ glutaraldehyde in $0.1 \mathrm{M}$ phosphate buffer (PB) at $\mathrm{pH} 7.2$ for $3 \mathrm{~h}$ at cold temperature $\left(2-4^{\circ} \mathrm{C}\right)$. The specimens were rinsed with $0.1 \mathrm{M}$ PB (three times) for $15 \mathrm{~min}$ at cold temperature and fixed with $1 \% \mathrm{O}_{\mathrm{s}} \mathrm{O}_{4}$ in $0.1 \mathrm{M}$ phosphate buffer for $2 \mathrm{~h}$ at cold temperature. After fixing, the specimens were rinsed with $0.1 \mathrm{M} \mathrm{PB}$ (three times) for $15 \mathrm{~min}$ at cold temperature. The specimens were then rinsed with distilled water and dehydrated in 50, 60, 70, 80, 90, 95\% and absolute ethanol for $15 \mathrm{~min}$ in each solution. After dehydration, specimens were settled in acetone for 15 min and critical point dried using hexamethyl-disilazane (HMDS; Sigma H-4875) three times for 20 min at cold temperature. The next specimens were mounted on a holder with double-sided tape and sputter-coated with gold using an ion-sputtering device (JFC-1100E, JEOL, 
Japan) twice for 10 and $20 \mathrm{~min}$. The accelerating voltage was $15 \mathrm{kV}$ and the working distance was $25 \mathrm{~min}$. The specimens were photographed using $\times 300$ magnification for muscle fiber microstructure evaluation.

\section{TBARS}

The 2-Thiobarbituric acid-reactive substance (TBARS) content of pork jerky samples from each treatment was determined using the TBA distillation procedure by Yang et al. (2009) as modified from a procedure by Sinnhuber and $\mathrm{Yu}$ (1977). A $0.4 \mathrm{~g}$ of pork jerky sample was weighed into a $30 \mathrm{~mL}$ screw capped pyrex tube (PYREX ${ }^{\circledR}$, USA). Two to 3 drops of antioxidant solution (A: $0.3 \mathrm{~g}$ butylated hydroxyl anisole $+5.4 \mathrm{~g}$ propylene glycol, B: $0.3 \mathrm{~g}$ butylated hydroxyl toluene $+4.0 \mathrm{~g}$ tween 20 ), $3 \mathrm{~mL}$ TBA (thiobarbituric acid) solution, and $17 \mathrm{~mL}$ TCA-HCl solution (trichloroacetic acid $+0.6 \mathrm{~N} \mathrm{HCl}$ ) were added. The mixture was vortexed and then incubated in a $100^{\circ} \mathrm{C}$ boiling water bath for $30 \mathrm{~min}$ to develop color. The sample was cooled in cold water for $10 \mathrm{~min}$. A $5 \mathrm{~mL}$ supernatant solution was transferred to the $10 \mathrm{~mL}$ glass tube, $2 \mathrm{~mL}$ chloroform was added and centrifuged for $15 \mathrm{~min}$ at $2,000 \times \mathrm{g}$. The absorbance of the resulting supernatant solution was determined at $532 \mathrm{~nm}$ against a blank containing all the reagents minus the sample.

TBARS (mg malonaldehyde/kg sample)

$=\{($ absorbance sample- absorbance blank $) \times 46\} /$ $\{$ sample weight $(\mathrm{g}) \times 5$ \}

\section{Sensory evaluation}

Eight panelists composed of faculty members and students from GNU (Gyeongsang National University) were trained in 3 training sessions. The panelists were given samples representing anchor points for attribute, and training sessions using pork jerky. The samples were evaluated for cured color intensity/redness (5 for "extremely red" and 1 for "slightly red"), cooked pork flavor (5 for "extremely intense" and 1 for "slightly intense"), juiciness (5 for "extremely juicy" and 1 for "not juicy"), tenderness( 5 for "very tender" and 1 for "though"), saltiness (5 for "very salty" and 1 for "not salty") and overall acceptability (5 for "like" and 1 for "dislike"). Final anchor point ratings were decided upon by the training panel after initial evaluation and discussion.

The panelists evaluated the samples for appearance, color, flavor, tenderness, juiciness, saltiness, and overall acceptability using a 9-point hedonic scale as described by Meilgaard et al. (1999). The panelists evaluated each characteristic of the sample using a 9-point hedonic scale, where 1 meant "extremely dislike" and 9 meant "extremely like." The saltiness was marked 1 for "weak" and 9 for "strong."

\section{Statistical analysis}

Data from three replications were analyzed by analysis of variance (ANOVA) using statistical analysis systems (SAS). ANOVA was adopted for designing mathematical model using SAS 9.2 (SAS Institute, Inc., USA). Duncan's multiple range tests were used to determine the statistical significance among the means (SAS, 2008) at $95 \%$ significant level.

\section{Results and Discussion}

\section{Moisture content and Water activity}

One important attribute of pork jerky is the ability to hold moisture after drying. The experimental data on moisture content and water activities of pork jerky were obtained during drying at $70^{\circ} \mathrm{C}$, after pre-soaking at $0 \%$, $2 \%, 5 \%$, and $10 \%$ salt concentrations (Figs. 1, 2, and 3). The moisture content for all pork jerky samples significantly decreased as drying proceeded up to $10 \mathrm{~h}(p<0.05)$. For up to $6 \mathrm{~h}$ of drying time, the moisture content of the sample decreased rapidly. The final moisture content of pork jerky samples which were pre-soaked at salt concentrations ranging from $2-10 \%$ was higher than that of the

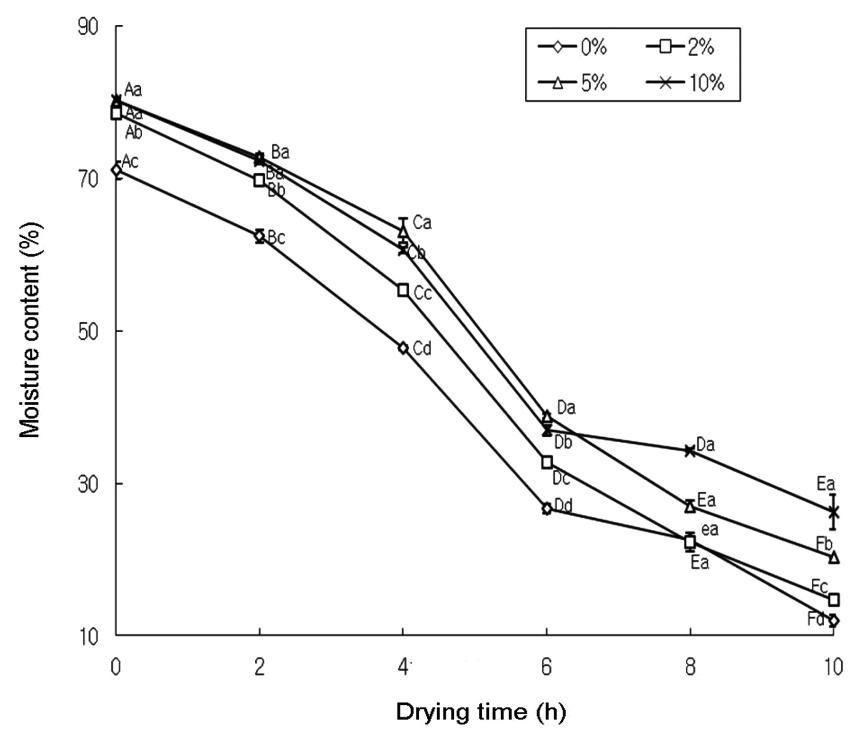

Fig. 1. Moisture content of pork jerky during drying at $70^{\circ} \mathrm{C}$ and soaked in different concentration of salt. Different capital letters indicate significant differences within drying times $(p<0.05)$. Different small letters indicate significant differences within each jerky samples $(p<0.05)$. 


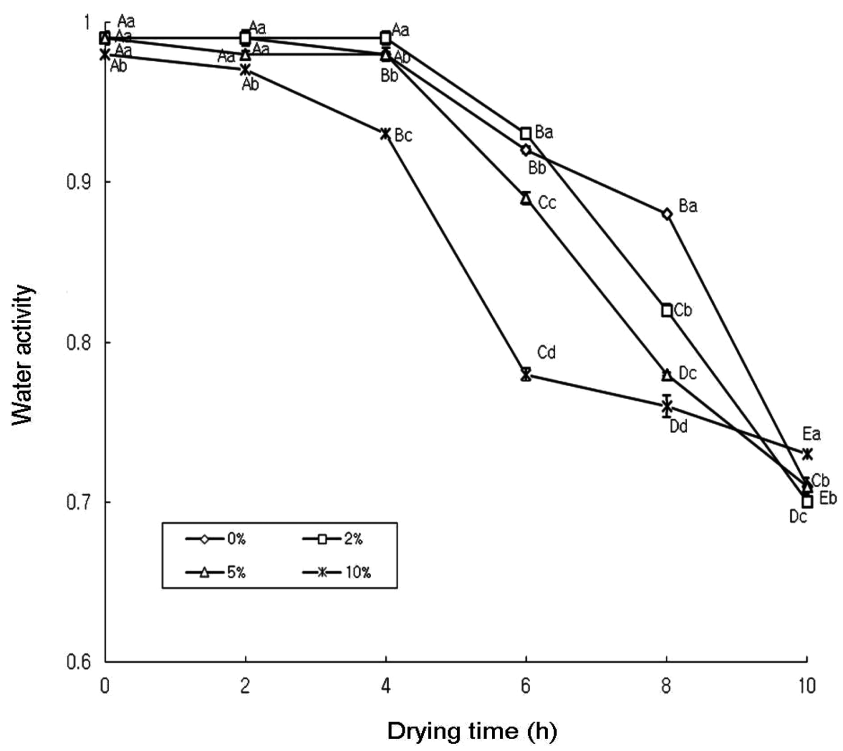

Fig. 2. Water activity of pork jerky during drying at $70^{\circ} \mathrm{C}$ and soaked in different concentration of salt. Different capital letters indicate significant differences within drying times $(p<0.05)$. Different small letters indicate significant differences within each jerky samples $(p<0.05)$.

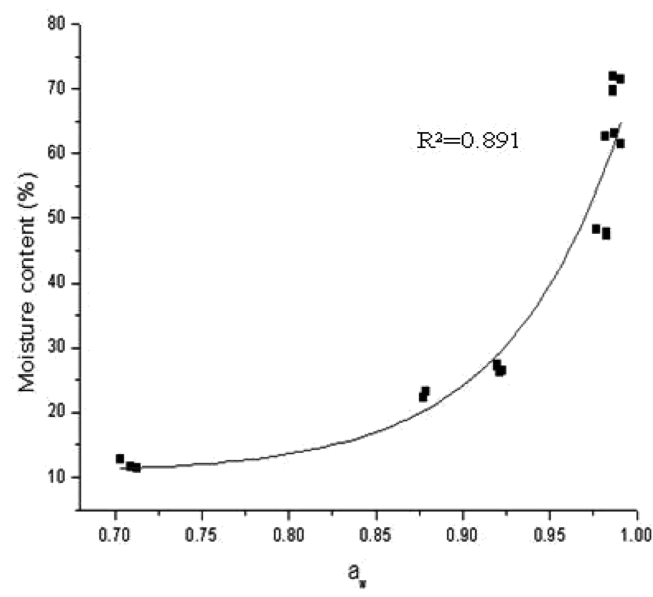

$0 \%$ salt content

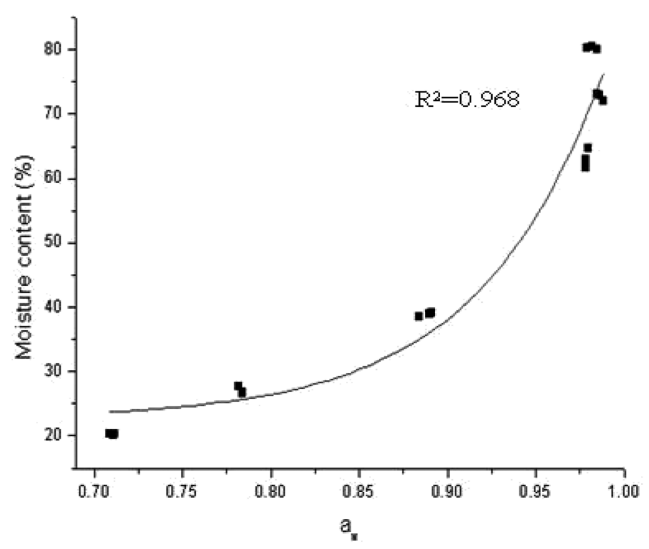

$5 \%$ salt content control sample without pre-soaking. The increase in the final moisture content of the products was pronounced with increasing salt concentration. In general, the $\mathrm{a}_{\mathrm{w}}$ for all pork jerky samples slowly decreased during drying for up to $4 \mathrm{~h}$, and the $\mathrm{a}_{\mathrm{w}}$ of all the samples rapidly decreased after $4 \mathrm{~h}$ of drying time. The $\mathrm{a}_{\mathrm{w}}$ of samples, which were pre-soaked in salt solutions decreased more rapidly with increasing salt concentration $(p<0.05)$. For example, the $\mathrm{a}_{\mathrm{w}}$ of samples, which were pre-soaked at $0,2,5$, and $10 \%$ salt solution, were $0.88,0.82,0.78$, and 0.76 at drying time of $8 \mathrm{~h}$, respectively. This could be explained by the fact that the process starts by simultaneous transport of water and salt and reaches the equilibrium point. In all cases, significant initial mass transfer rates and progressive diminution later were observed due to an increase in the drying time. As the diminution rate is smaller for more concentrated sodium chloride (w/w), the effect of the operating drying condition and its influence on the osmotic dehydration parameters were analyzed as first variable. As could be expected, an increase in the drying time

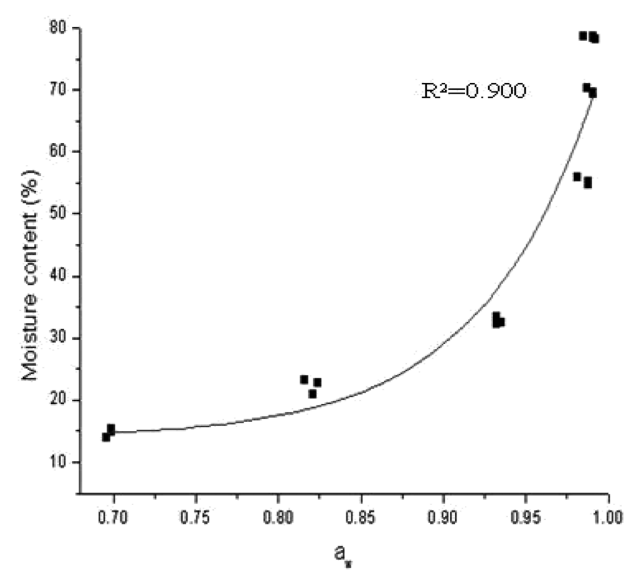

$2 \%$ salt content

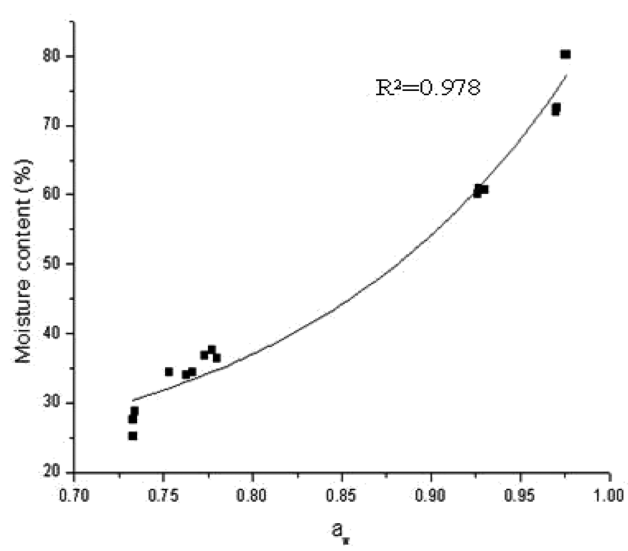

$10 \%$ salt content

Fig. 3. The relationship between moisture content and water activity of pork jerky soaked in different salt solution prior to drying. 
made dehydration more intense, reaching lower values of moisture content. This behavior was observed for all the assayed concentration, although the intensity of the effect was higher with the most concentrated salt solutions. The moisture content decreased continuously because of the combined action of high temperature drying condition, which causes a muscular contraction, and the strong salt concentration gradient between the meat and the soaking solution. The water activity $\left(\mathrm{a}_{\mathrm{w}}\right)$ and moisture content decreased along with the increase in salt level and drying time. During salting process, the muscle takes up salt and loses water, and salting and dehydration result in decreased water activity (Thorarinsdottir et al., 2001).

On the other hand, the relationship between moisture content and water activity in pork jerky with all the data obtained from various salt concentrations and drying time is represented in Fig. 3. The predicted curves for pork jerky samples obtained by fitting experimental data showed the high correlation coefficient between moisture content and $\mathrm{a}_{\mathrm{w}}$ with values of $0.891,0.900,0.968$, and 0.973 at $0 \%, 2 \%, 5 \%$, and $10 \%$ salt concentrations, respectively. The predicted moisture content of pork jerky at $0.85 \mathrm{a}_{\mathrm{w}}$, which might produce better textured pork jerky with microbial safety, were $23 \%, 29 \%, 37 \%$, and $47 \%$ at $0 \%, 2 \%, 5 \%$, and $10 \%$ salt concentrations, respectively. The results indicate that the moisture content of pork jerky at intermediate moisture levels, especially ranging at $0.70-0.85 \mathrm{a}_{\mathrm{w}}$, increases pre-soaking at salt solution. In addition, these results may lead to providing a softer texture for pork jerky. This relationship between moisture content and $\mathrm{a}_{\mathrm{w}}$ may be very effective for not only quality but also sensory properties including hardness and taste quality. This would be one of the benefits of controlling the textural property of pork jerky. The concept of $\mathrm{a}_{\mathrm{w}}$ has been useful in food preservation and based on the concept, many processes could be successfully adopted for designing new products (van der Berg, 1991). Again, specific changes in flavor, texture, stability, and acceptability of raw and processed meat products have been associated with relatively narrow $\mathrm{a}_{\mathrm{w}}$ ranges (Chang et al., 1991). Yang (2000) managed to make semidried beef jerky with higher moisture content $\left(\mathrm{a}_{\mathrm{w}} 0.85\right)$ and improved textural property.

\section{Shear force}

One of the most important attributes of jerky is the hardness that can be measured as shear force. Shear force values can be used to characterize the intermediate moisture products and be defined as the maximum force attained as a blade is sheared through pork jerky samples. The results of pork jerky samples with different drying time and various salt concentrations are shown in Table 1.

The shear force values of the samples varied from 14.41 to $2.74 \mathrm{~N}\left(\mathrm{~kg} \cdot \mathrm{m} / \mathrm{sec}^{2}\right)$ in accordance to the drying time and salt concentration. As expected, the shear force value increased dramatically with increasing drying time $(p<0.05)$. It was clear that the elevation of shear force through increased drying time was due to decreasing moisture content and that decrease in shear force by presoaking in salt solutions was related to an increase in the water holding capacities of jerky samples by addition of salt. Both drying time and salt concentration were significant factors affecting the shear force. These results are consistent with those reported by other researchers such as Trott et al. (1992) and Fanbin et al. (2008). They suggested that a decrease in the hardness of meat products by

Table 1. Shear force and water activity of pork jerky during drying at $70^{\circ} \mathrm{C}$ and soaked in different concentration of salt

\begin{tabular}{|c|c|c|c|c|c|c|}
\hline \multirow{2}{*}{$\begin{array}{l}\text { Salt content } \\
(\%)\end{array}$} & \multicolumn{6}{|c|}{ Drying time (h) } \\
\hline & 0 & 2 & 4 & 6 & 8 & 10 \\
\hline \multicolumn{7}{|c|}{ Shear force $\left(\mathrm{kg} / \mathrm{cm}^{2}\right)$} \\
\hline 0 & $6.94 \pm 0.99^{\mathrm{Ae}}$ & $9.30 \pm 1.07^{\mathrm{Ad}}$ & $10.55 \pm 0.92^{\text {Acd }}$ & $11.56 \pm 1.88^{\mathrm{Abc}}$ & $12.91 \pm 1.58^{\mathrm{Aab}}$ & $14.41 \pm 0.84^{\mathrm{Aa}}$ \\
\hline 2 & $4.12 \pm 1.19^{\mathrm{BCd}}$ & $8.17 \pm 1.13^{\mathrm{Bc}}$ & $9.18 \pm 1.31^{\mathrm{Cb}}$ & $10.36 \pm 0.82^{\mathrm{Ba}}$ & $12.13 \pm 0.80^{\mathrm{Ba}}$ & $12.61 \pm 1.36^{\mathrm{Ca}}$ \\
\hline 5 & $2.74 \pm 0.53^{\mathrm{Bd}}$ & $6.27 \pm 0.83^{\mathrm{Ac}}$ & $7.34 \pm 1.11^{\mathrm{Bbc}}$ & $9.05 \pm 0.78^{\mathrm{ABb}}$ & $9.68 \pm 0.37^{\mathrm{Aa}}$ & $11.65 \pm 1.42^{\mathrm{Ba}}$ \\
\hline 10 & $3.22 \pm 0.84^{\mathrm{Cd}}$ & $5.28 \pm 0.76^{\mathrm{Bc}}$ & $6.68 \pm 0.50^{\mathrm{Cc}}$ & $9.13 \pm 0.45^{\mathrm{Bb}}$ & $9.24 \pm 0.51^{\mathrm{Bb}}$ & $9.88 \pm 0.39^{\mathrm{Ba}}$ \\
\hline \multicolumn{7}{|c|}{ Water activity } \\
\hline 0 & $0.998 \pm 0.003^{\mathrm{Aa}}$ & $0.987 \pm 0.005^{\mathrm{Aab}}$ & $0.981 \pm 0.003^{\mathrm{ABb}}$ & $0.921 \pm 0.002^{\mathrm{Bc}}$ & $0.878 \pm 0.001^{\mathrm{Ad}}$ & $0.708 \pm 0.006^{\mathrm{Be}}$ \\
\hline 2 & $0.989 \pm 0.004^{\mathrm{Aa}}$ & $0.990 \pm 0.002^{\mathrm{Aa}}$ & $0.986 \pm 0.004^{\mathrm{Aa}}$ & $0.933 \pm 0.002^{\mathrm{Ab}}$ & $0.820 \pm 0.004^{\mathrm{Bc}}$ & $0.698 \pm 0.002^{\mathrm{Cd}}$ \\
\hline 5 & $0.982 \pm 0.003^{\mathrm{Bb}}$ & $0.986 \pm 0.002^{\mathrm{Aa}}$ & $0.979 \pm 0.001^{\mathrm{Bb}}$ & $0.888 \pm 0.004^{\mathrm{Cc}}$ & $0.783 \pm 0.001^{\mathrm{Cd}}$ & $0.711 \pm 0.002^{\mathrm{Be}}$ \\
\hline 10 & $0.975 \pm 0.001^{\mathrm{Ca}}$ & $0.970 \pm 0.001^{\mathrm{Ba}}$ & $0.928 \pm 0.002^{\mathrm{Cb}}$ & $0.777 \pm 0.004^{\mathrm{Dc}}$ & $0.761 \pm 0.007^{\mathrm{Dd}}$ & $0.733 \pm 0.001^{\mathrm{Ae}}$ \\
\hline
\end{tabular}

Results are expressed as means $\pm \mathrm{SD}$

${ }^{A-C}$ Means in the same column with different superscript capital letters are significantly different $(p<0.01)$.

${ }^{\mathrm{a}-\mathrm{e}}$ Means in the same row with different superscript small letters are significantly different $(p<0.01)$. 
the addition of texture-modifying ingredients may be associated with the water binding properties of the ingredients, such as soy protein, starch, and salt (that is, the ingredient may help absorb and retain moisture).

\section{Microstructure}

The microstructure of pork jerky samples, which were pre-soaked in salt solutions ranging from 0 to $10 \%$, prior to drying at $70^{\circ} \mathrm{C}$ for $10 \mathrm{~h}$, is shown in Fig. 4. The SEM micrographs showed that muscle with the addition of salt had smaller conglomerates and that muscle fiber with salt treatment had wider diameter than that of the control sample without salt treatment. The gaps between fibres and endomysial tubes from pork jerky samples presoaked in salt solutions were very clear. The phenomenon was profounded with increasing salt concentrations. This result was consistent with previous studies (Offer and Knight, 1988). These modifications of the myofibril morphology are probably due to the solubilization of myosin because of the increase in ionic strength following salt addition (Offer and Knight, 1988; Offer and Trinick, 1983). SEM micrographs of pork jerky may provide information on the structural features of the muscle as influenced by the addition of salt and may give an insight on the relationship between water binding property or textural attributes and the structure of meat microstructure.

\section{TBARS (2-thiobarburic acid reactive substance)}

TBARS value is the most common indicator used to measure the degree of lipid oxidation in meat products (Obanu, 1988). The TBARS values of pork jerky samples were gathered to investigate the effect of the addition of salt on lipid oxidation during drying at $70^{\circ} \mathrm{C}$. The results are shown in Table 2. TBARS values of jerky samples were significant $(p<0.05)$ by both salt concentration and drying time. For all samples at various salt solutions, TBARS values became higher as drying time increased. By the addition of salt, TBARS values were higher than those of control samples. Such increase in TBARS values was profounded with increasing salt concentrations. Sár-

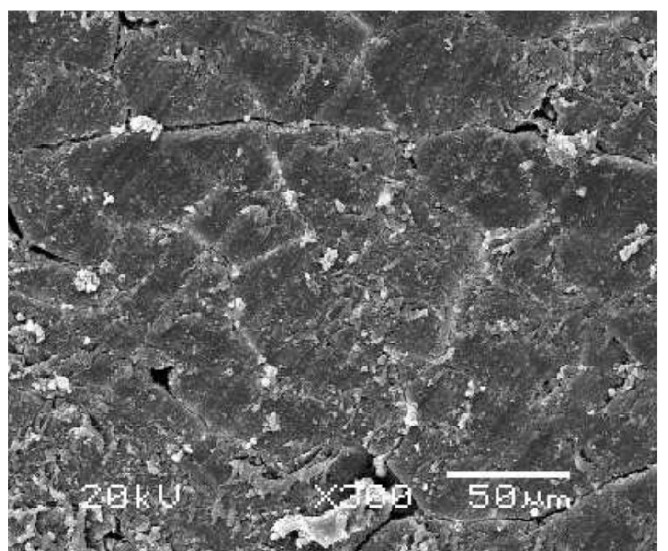

$0 \%$ salt content

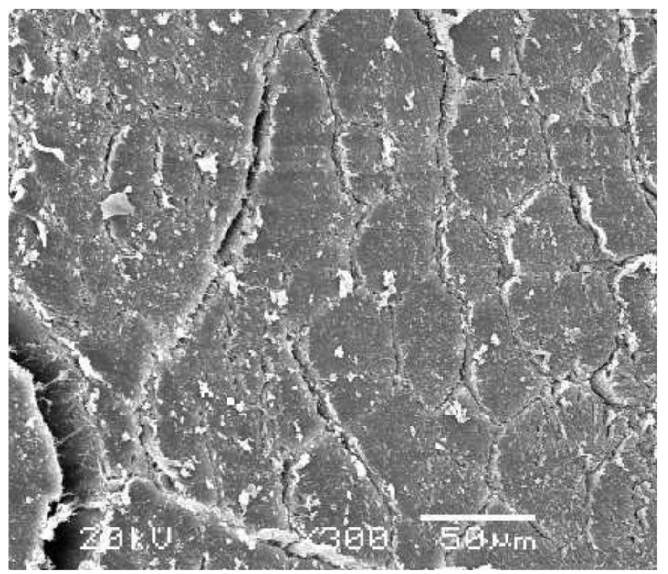

$5 \%$ salt content

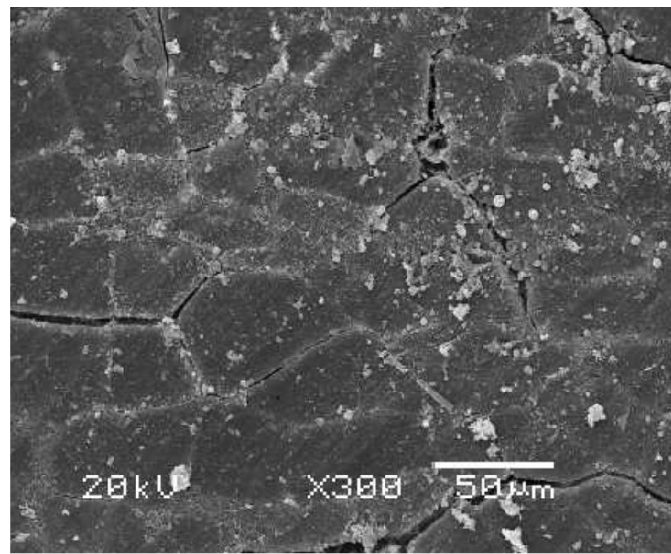

$2 \%$ salt content

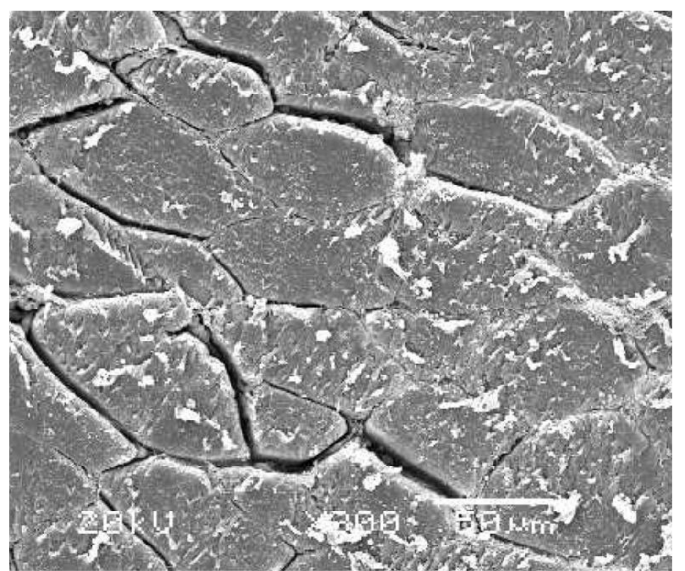

$10 \%$ salt content

Fig. 4. SEM (scanning electron microscope) photographs of pork jerky during drying at $70^{\circ} \mathrm{C}$ for $10 \mathrm{~h}$ and soaked in different concentration of salt. 
Table 2. TBARS of pork jerky during drying at $70^{\circ} \mathrm{C}$ and soaked in different concentration of salt

\begin{tabular}{ccccccc}
\hline \multirow{2}{*}{$\begin{array}{c}\text { Salt content } \\
(\%)\end{array}$} & 0 & 2 & 4 & 6 & 8 & 10 \\
\cline { 2 - 7 } & & \multicolumn{5}{c}{ TBARS (mg MA/kg) } \\
0 & $1.04 \pm 0.01^{\mathrm{Cc}}$ & $1.16 \pm 0.05^{\mathrm{Cc}}$ & $1.19 \pm 0.03^{\mathrm{Cc}}$ & $2.29 \pm 0.14^{\mathrm{Cb}}$ & $2.62 \pm 0.78^{\mathrm{Ca}}$ & $2.34 \pm 0.10^{\mathrm{Db}}$ \\
2 & $1.15 \pm 0.05^{\mathrm{BC}}$ & $1.14 \pm 0.05^{\mathrm{Cd}}$ & $1.70 \pm 0.16^{\mathrm{Bc}}$ & $2.91 \pm 0.05^{\mathrm{Bb}}$ & $4.34 \pm 0.07^{\mathrm{Ba}}$ & $3.83 \pm 0.31^{\mathrm{Ca}}$ \\
5 & $1.22 \pm 0.12^{\mathrm{ABe}}$ & $1.33 \pm 0.13^{\mathrm{Be}}$ & $1.83 \pm 0.06^{\mathrm{Bd}}$ & $4.15 \pm 0.10^{\mathrm{Ac}}$ & $5.17 \pm 0.24^{\mathrm{Aa}}$ & $4.71 \pm 0.58^{\mathrm{Bb}}$ \\
10 & $1.36 \pm 0.11^{\mathrm{Ad}}$ & $1.76 \pm 0.09^{\mathrm{Ad}}$ & $2.52 \pm 0.13^{\mathrm{Ac}}$ & $4.55 \pm 0.40^{\mathrm{Ab}}$ & $5.47 \pm 0.18^{\mathrm{Aa}}$ & $5.45 \pm 0.22^{\mathrm{Aa}}$ \\
\hline
\end{tabular}

Results are expressed as means $\pm \mathrm{SD}$

${ }^{\mathrm{A}-\mathrm{C}}$ Means in the same column with different superscript capital letters are significantly different $(p<0.01)$.

${ }^{\mathrm{a}-\mathrm{e}}$ Means in the same row with different superscript small letters are significantly different $(p<0.01)$.

raga and Garæia-Regueiro (1998) represented that lipid oxidation of jerky measured by TBARS was dependent on salt concentrations. For example, a product with an addition of $1-3 \%$ salt concentration produced lower TBARS values than non-salted samples, whereas the product with $5 \%$ salt addition produced higher TBARS values, leading to higher lipid oxidative activity. In our study, we found that there was no significant effect among salt concentrations ranging from 0 to $2 \%$ on lipid oxidation. However, there are significant above salt concentrations of $5 \%$. It seems that the processing temperature and salt may help to form malonaldehyde formation throughout the ripening in high salt concentration. O'Neill et al. (1999) reported that the MDA-TBA values of refrigerated, cooked thigh meat patties of chicken were significantly higher in patties with added salt than the control patties that were unsalted. Coutron-Gambotti et al. (1999) found that higher salt content did not increase rancidity.

\section{Sensory evaluations}

The sensory panels convened to assess the effect of presoaking salt concentration on the color, flavor, juiciness, tenderness, saltiness, and overall acceptability of pork jerky samples after drying at $70^{\circ} \mathrm{C}$ for $10 \mathrm{~h}$ (Table 3 ).

All sensory attributes became significant $(p<0.05)$ by pre-soaking at salt solution compared to control samples without pre-soaking. Color, flavor, and juiciness scores were improved by the addition of salt, but the concentra- tion of salt was not significant $(p<0.05)$. For the tenderness and saltiness of pork jerky samples, the ones presoaked at higher salt solution produced higher scores $(p<0.05)$. The overall acceptability scores of pork jerky samples ranged from 1.65 to 7.23 , and the maximum acceptability was obtained from the jerky sample, which was pre-soaked at $2 \%$ salt solution prior to drying. This may be due to better flavor and texture characteristics. The pork jerky samples pre-soaked at 5 or $10 \%$ salt solutions produced lower scores in overall acceptability, mainly due to excessive saltiness.

\section{Conclusion}

The physicochemical properties of pork jerky were affected by pre-soaking in salt solution and drying time. The moisture content of pork jerky pre-soaked in salt solutions decreased more rapidly during drying at $70^{\circ} \mathrm{C}$ than that of the control jerky. However, the final moisture content of pork jerky pre-soaked in $10 \%$ salt solution was the highest among the samples. The relationship between moisture and $\mathrm{a}_{\mathrm{w}}$ for pork jerky samples with/without presoaking fit well with high concentration coefficients $\left(\mathrm{R}^{2}\right)$ $0.93,0.92,0.95$, and 0.98 . The shear force values increased with increasing drying time and decreased with increasing salt concentration. The gap between fibres and endomysial tubes were clearly observed in salt-treated pork jerky by SEM. This may imply that salt treatment

Table 3. Sensory evaluation of pork jerky during drying at $70^{\circ} \mathrm{C}$ for $10 \mathrm{~h}$ and soaked in different concentration of salt

\begin{tabular}{ccccccc}
\hline \hline Salt conc. (\%) & Color & Flavor & Juiciness & Tenderness & Saltiness & Overall acceptability \\
\hline 0 & $2.43 \pm 0.51^{\mathrm{B}}$ & $4.03 \pm 0.14^{\mathrm{B}}$ & $2.88 \pm 0.26^{\mathrm{C}}$ & $2.05 \pm 0.27^{\mathrm{C}}$ & $1.03 \pm 0.14^{\mathrm{D}}$ & $3.65 \pm 0.39^{\mathrm{B}}$ \\
2 & $5.88 \pm 0.41^{\mathrm{A}}$ & $5.25 \pm 0.18^{\mathrm{A}}$ & $5.60 \pm 0.23^{\mathrm{B}}$ & $4.50 \pm 0.20^{\mathrm{B}}$ & $3.65 \pm 0.43^{\mathrm{C}}$ & $7.23 \pm 0.18^{\mathrm{A}}$ \\
5 & $6.40 \pm 0.25^{\mathrm{A}}$ & $5.40 \pm 0.22^{\mathrm{A}}$ & $6.75 \pm 0.25^{\mathrm{A}}$ & $5.55 \pm 0.38^{\mathrm{AB}}$ & $7.48 \pm 0.20^{\mathrm{B}}$ & $2.95 \pm 0.19^{\mathrm{B}}$ \\
10 & $5.35 \pm 0.23^{\mathrm{A}}$ & $5.58 \pm 0.42^{\mathrm{A}}$ & $7.55 \pm 0.30^{\mathrm{A}}$ & $6.18 \pm 0.57^{\mathrm{A}}$ & $9.30 \pm 0.19^{\mathrm{A}}$ & $1.65 \pm 0.37^{\mathrm{C}}$ \\
\hline
\end{tabular}

Results are expressed as means \pm SD

${ }^{A-C}$ Means in the same column with different superscripts are significantly different $(p<0.01)$. 
induces structural change of muscle and leads to a decrease in hardness. The highest overall acceptability score in pork jerky products was obtained by pre-soaking in $2 \%$ salt solution, prior to drying.

\section{References}

1. AOAC (2000) Official methods of analysis. Association of Official Analytical Chemists. 17th ed. Gaithersburg, MD.

2. Barat, J. M., Rodriguez-Barona, S., Andrés, A., and Fito, P. (1998) Influence of increasing brine concentration in the cod-salting press. J. Food Sci. 67, 1922-1925.

3. Carroll, R. J. and Lee, C. M. (1981) Meat emulsions: Fine structure relationships and stability. Scanning Electron Microscopy. pp. 447.

4. Chang, S. F., Huang, T. C., and Pearson, A. M. (1991) Some parameters involved in production of Zousoon - A semi-dry, long fibered pork product. Meat Sci. 30, 303-325.

5. Chenlo, F., Moreira, R., Fernández-Herrero, C., and Vázquev, G. (2006) Mass transfer during dehydration of chestnut using sodium chloride solutions. J. Food Eng. 73, 164-173.

6. Coutron-Gambotti, C., Gandemer, G., Rousset, S., Maestrini, O., and Casabianca, F. (1999) Reducing salt content of drycured ham: effect on lipid composition and sensory attributes. Food Chem. 64, 13-19.

7. Detienne, N. A. and Wicker, A. (1999) Sodium chloride and tripolyphosphate effects on physical and quality characteristics of injected pork loins. J. Food Sci. 64, 1042-1047.

8. Fanbin, K., Alexandra, O., Juming, T., Barbara, R., and Chuck, C. (2008) Salt effect on heat-induced physical and chemical changes of salmon fillet (O. gorbuscha). Food Chem. 106, 957-966.

9. Gailani, D. M. and Fung, D. Y. C. (1986) Critical review of water activities and microbiology of drying of meats. Crit. Rev. Food Sci. Nutr. 25, 159-183.

10. Harrison, J. A., Harrison, M. A., and Rose, R. A. (1997) Fate of Listeria monocytogenes and Salmonella species in ground beef jerky. J. Food Prot. 60, 1139-1141.

11. Lazarides, H. N., Katsanidis, E., and Nickolaidis, A. (1995) Mass transfer kinetics during osmotic preconcentration aiming at minimal solid uptake. J. Food Sci. 25, 151-166.

12. Meilgaard, M., Civille, G. V., and Carr, B. T. (1999) Sensory evaluation techniques. 3 rd ed. Boca Ration, FL:CRC Press, p. 354.

13. Obanu, Z. A. (1988) Preservation of meat in Africa by control of the internal aqueous environment in relation to product quality and stability. In: Food Preservation by Moisture Control. 2nd ed. Elsevier Applied Science, London, pp. 68.

14. Offer, G. and Knight, P. (1988) The structural basis of waterholding in meat. In: Developments in Meat Science. Lawire,
R. (ed). Elsevier Science, London, pp. 63-171.

15. Offer, G. and Trinick, J. (1983) On the mechanism of water holding in meat: The swelling and shrinking of myofibrils. Meat Sci. 8, 245-281.

16. O’Neill, L. M., Galvin, K., and Buckley, D. J. (1999) Effect of carnosine, salt and dietary vitamin $\mathrm{E}$ on the oxidative stability of chicken meat. Meat Sci. 52, 89-94.

17. Pearson, A. M. and Wolzak, A. M. (1982) Salt-its use in animal products-A human health dilemma. J. Anim. Sci. 54, 1263-1278.

18. Quinton, R. D., Cornforth, D. P., Hendricks, D. G., Brennand, C. P., and Su, Y. K. (1997) Acceptability and composition of some acidified meat and vegetable stick products. J. Food Sci. 62, 1250-1254.

19. Rahman, M. S. (1992) Osmotic dehydration kinetics of food. Indian Food Industry 15, 20-24.

20. Sárraga, C. and Garæia-Regueiro, J. A. (1998) Oxidation of microsomal fraction in the processing conditions of drycured ham. The in-vitro effect of brine. Meat Sci. 50, 295302.

21. SAS (2000) SAS/STAT Software for PC. Release 8.2, SAS Institude Inc., Cary, NC, USA.

22. Sinnhuber, R. O. and Yu, T. C. (1977) The 2-thiobarbituric acid reaction, an objective measure of the oxidative determination occurring in fats and oils. J. Jpn. Oil Chem. Soc. 26, 259-267.

23. Thorarinsdottir, K. A., Arason, S., Bogason, S. G., and Kristbergsson, K. (2001) Effects of phosphate on yield, quality, and water-holding capacity in the processing of salted cod (Gadus morhua). J. Food Sci. 66, 821-826.

24. Torres, E. A. F. S., Shimokomaki, M., Franco, B. D. G. M., Carvalho Jr, B. C., and Santos, J. C. (1994) Parameter determining the quality of charqui, an intermediate moisture meat product. Meat Sci. 38, 229-234.

25. Troutt, E. S., Hunt, M. C., Johnson, D. E., Claus, J. R., Kastner, C. L., and Kropf, D. H. (1992) Characteristics of low fat ground beef containing texture modifying ingredients. $J$. Food Sci. 57, 19-24.

26. van der Berg, C. (1991) Food-water relations: Process and integration, comments and thoughts. In: Water Relations in Foods. Levine, H. and Slade L. (eds), Pleunm Press, NY, pp. 21-28.

27. Yang, H. S., Kang, S. W., Jeong, J. Y., Chun, J. Y., Joo, S. T., Park, G. B., and Choi, S. G. (2009) Optimization of Drying Temperature and Time for Pork Jerky using response surface methodology. Food Sci. Biotechnol. 18, 985-990.

28. Yang, M. S. (2000) Effects of antioxidants on the quality of beef jerky during storage. MS thesis, Sejong Univ., Seoul, Korea.

(Received 2012.1.4/Revised 1st 2012.3.20, 2nd 2012.4.30, 3rd 2012.5.2/Accepted 2012.5.20) 